\title{
Inverse Age Resistance to Experimental Babesia Divergens Infection in Cattle.
}

\author{
By Dan A. Christensson \\ Department of Veterinary Microbiology, Section of Parasitology, Swedish University of \\ Agricultural Sciences and the National Veterinary Institute, Uppsala, Sweden.
}

\begin{abstract}
Christensson, D. A.: Inverse age resistance to experimental Babesia divergens infection in cattle. Acta vet. scand. 1989, 30, 453-464. - Two groups of calves, 1.5-2 and 7-11 months old respectively, and dairy cows were inoculated i.v. with $3 \times 10^{7}$ erythrocytes infected with Babesia divergens.

High parasitaemia, fever and other clinical signs of babesiosis occurred among adult animals. A very low parasitaemia and a slightly increased body temperature but no other symptoms occurred in calves. These findings substantiate the conclusion that there exists an inverse age resistance against Babesia divergens. The kinetics of $B$. divergens IgG antibody formation were similar in all age groups. Consequently this antibody response was not the factor determining the development of the primary parasitaemia and thus the inverse age resistance phenomenon.

However, age is not necessarily the only factor involved in the clinical expression of babesiosis. The kinetics of antibody formation was not associated with the intensity of the parasitaemia. In fact only about half the animals had a demonstrable parasitaemia although the antibody responses were similar in all age groups.
\end{abstract}

clinical babesiosis; IgG.

\section{Introduction}

There is a plethora of field reports that adult cattle are more likely to fall ill with babesiosis than calves (Smith \& Kilborne 1893, Pound 1897, Kragerüd 1901, Bergman \& Waxberg 1915, Klarin 1925, Hinderson 1928, Legg 1933, Riek 1968, Pipano 1969, Callow 1977, Callow \& Dalgliesh 1982, Taylor et al. 1983, Gray et al. 1983, Gray \& Murphy 1985, Christensson \& Thorburn 1987, Christensson \& Enfors 1987, and others). The phenomenon of inverse age resistance has been associated with maternally transferred immunity (Hall 1960, 1963, Hall et al. 1968) and from observations reported by Ross \& Löhr (1970) and Weisman et al. (1974). However, this explanation is not generally accepted (Riek 1968, Callow \& Dalgliesh 1982).
There is a limited number of experimental studies on the inverse age resistance phenomenon of babesiosis, each elucidating only isolated parameters. Trueman \& Blight (1978) showed that clinical symptoms and packed cell volume (PCV) values differed between 6-months-old calves, yearlings and adults after inoculation with Babesia bovis. Latif et al. (1979) found that yearlings, in contrast to calves, were highly susceptible to $B$. bigemina but they found no serological difference between groups. In other experimental studies, which primarily dealt with other problems of babesiosis, there is information showing that there may exist an inverse age resistance to Babesia in cattle (Smith et al. 1978, Taylor et al. 1983). However, Löhr (1969) and Brocklesby et al. (1971) who were working with $B$. bigemina 
and B. divergens respectively, found no difference between clinical haematological responses in adults and calves.

Although there is conflicting information available, there is circumstantial evidence that there may exist an inverse age resistance to $B$. divergens, the only Babesia species demonstrated in Swedish cattle. However, this phenomenon is not completely explained.

The aim of the present study was to define the susceptibility of previously unexposed cattle of different ages to experimentally inoculated $B$. divergens. In the planning of the study parameters of relevance to the Swedish Babesia vaccination program were taken into consideration.

\section{Materials and methods Animals}

Two groups of calves and 2 groups of cows were used for experimental inoculation of $B$. divergens as summarized in Table 1.

Group 1 comprised 5 calves, 1.5-2 months old, born and raised indoors at the University farm. Two calves were males and 3 were females.

Group 2 comprised 10 male castrates, 7-11 months old, born and raised indoors on a commercial farm (A). The stock had after end of grazing season moved from a Babesia-free area into an infected area. Experiment was made during the indoor season.

Group 3 comprised 13 dairy cows in their first lactating period, having had their calf 46 months before. They were 34-38 months old. These animals were also part of farm A. They were born and raised on the original farm. There were 11 more cows on the farm, not participating in the experiments beyond a serum test for Babesia.

Group 4 comprised 11 dairy cows belonging to another commercial farm (B) which also moved their stock from a Babesia-free area to an infected farm. The experiment was performed indoors before animals were put on the new, infected pasture. Besides a primary serological test for Babesia, these animals were investigated only with regard to body temperature and other clinical observations.

All of the animals used were of the Swedish Red and White breed except in Group 1, where the 3 female calves were cross breed Swedish Red and White and Swedish Frisian breed.

All animals, including the other 11 cows on farm $\mathrm{A}$, were $B$. divergens-seronegative when tested a week before inoculation. They were clinically healthy for at least 1 months before inoculation. Throughout an observation period of at least 2 months, only symptoms of babesiosis following the inoculations were observed.

With regard to the risk of animals contracting uncontrolled babesiosis on grass, the experimental inoculations were sanctioned by

Table 1. Data of experimental animals

\begin{tabular}{llcccc}
\hline Group no. Exp. sites & $\begin{array}{c}\text { No. of } \\
\text { animals }\end{array}$ & $\begin{array}{c}\text { Age range } \\
\text { (months) }\end{array}$ & Sex & Remarks \\
\hline Calves & Univ. farm & 5 & $1.5-2$ & $2 \mathrm{m,} 3 \mathrm{f}$ & Born and raised on camp. \\
1 & Herd A & 10 & $7-11$ & $\mathrm{~m}$ & Born and raised on the farm (indoor). \\
2 & Herd A & 13 & $34-38$ & $\mathrm{f}$ & First lactation period. Pastured in Babesia-free area. \\
Cows & Herd B & 11 & $>30$ & f & Lactating, pastured in Babesia-free area. \\
3 &
\end{tabular}

$\mathrm{f}=$ females, $\mathrm{m}=$ males 
the farmers, provided that animals falling ill with babesiosis were treated.

\section{Inoculation}

All of the animals were inoculated intravenously (i.v.) with $3 \times 10^{7}$ erythrocytes (rbc) infected with Babesia divergens parasites. The inoculum had a volume of $3 \mathrm{ml}$. It consisted of a fresh prepared live vaccine for babesiosis as described by Callow (1977) and modified as previously described by Christensson \& Morén (1987).

The infective dose of Babesia organisms was that of the vaccine dose which is given subcutaneously.

Group 2 and 3 were inoculated on the same day using the same passage of isolate 1/78. Group 1 and Group 4 respectively, were inoculated with other passages of the same isolate. All animals were kept indoors for a subsequent observation period of 3-4 weeks.

\section{Blood samples}

Jugular blood samples were collected on Day 0 (day of inoculation), Day 3 and thereafter daily to Day 11 p.i. Subsequently, samples were collected every other day until Day 21 p.i. with some irregularities. From Group 1 there was also a sample on Days 23 and 30 p.i.

Blood for haematological examination was drawn into heparinized test tubes, while blood for serological tests was drawn into non-heparinized test tubes. Serum was separated by centrifugation and store at $-20^{\circ} \mathrm{C}$ until used.

\section{Parasitaemia}

The parasitaemia was investigated on thin films stained with acridine-orange (Winter 1967, Trees 1974). The number of red blood corpuscles (rbc) was counted using an ocular grid with $10 \times 10$ squares. One infected rbc per $10^{6} \mathrm{rbc}$ was the minimum count for a sample to be designated positive and consequently the limit for the designation parasitaemia.

\section{Haematological parameter}

The PCV established on p.i. Day 0 and 3 and then alternate days with a Linson microhaematocrit centrifuge.

\section{Body temperature}

Rectal body temperatures were measured daily from Day 0 until Day 13 p.i. and then every other day until Day 21 p.i., on Day 30 in Group 1. In Group 4 the temperature was recorded from Day 5 p.i. until Day 11 p.i. The lowest temperature for febrile reaction was stipulated to be $39.4^{\circ} \mathrm{C}$ as previously suggested (Purnell \& Brocklesby 1977, Purnell \& Lewis 1981, Taylor et al. 1983).

\section{Other clinical observations}

Clinical observations were made daily with regard to appetite, listlessness, consistency of faeces, and color of the urine. For the animals in Group 3 the farmer also estimated the daily individual drop of milk production in 4 steps, $25 \%, 50 \%, 75 \%$ and $100 \%$ of normal yield (scored $25 \%=1$ to $100 \%=4$ ).

\section{Serology}

The serum antibodies to $\boldsymbol{B}$. divergens were established by a modified IF-technique (Christensson 1987a) using FITC-protein A on rabbit anti-bovine IgG (Miles, Ltd). The IgG titres were established on Day 0, 3 and every other day, as described above. The lowest positive titre was stipulated to $1 / 40$.

Sera giving an unspecific fluorescence at $1 / 40$ were not found to have any stronger fluorescence at $1 / 20$ when retested.

\section{Statistical calculations}

The Mann \& Whitney (Wilcoxon) rank-sum test, and $\mathrm{X}^{2}$-test with Yates correction were used in the statistical calculations. 
Table 2. Parasitaemia: Number of animals with a demonstrable parasitaemia and the number of infected erythrocytes per $10^{6} \mathrm{rbc}$ in cattle experimentally inoculated with $B$. divergens.

\begin{tabular}{lccccc}
\hline Group & $\begin{array}{c}\text { No. of } \\
\text { animals }\end{array}$ & $\begin{array}{c}\text { Babesia divergens } \\
\text { positive animals } \\
\mathrm{n}\end{array}$ & $\begin{array}{c}\text { Average no. of } \\
\text { inf. rbc per animal }\end{array}$ & $\begin{array}{c}\text { Individual maximal no } \\
\text { inf. rbc }\end{array}$ \\
\hline Calves & 5 & 2 & 40 & 1 & 3,1 \\
1 & 0 & 4 & 40 & 1 & $6,2,1,1$ \\
2 & 13 & 10 & 77 & 7054 & $26000,12000,10000,10000,5100$, \\
Cows & & & & & $5000,2100,10,10,1$ \\
\hline
\end{tabular}

\section{Treatment}

In Groups 2 and 3 the indication to treat was a rectal temperature of $\geq 40^{\circ} \mathrm{C}$. In Group 4 the indication to treat was haematuria. The chemotherapeutic used was chinuridmethylsulphate (Acaprin ${ }^{\circledR}$, Bayer).

Because some cows were treated and some were not, the results from these are shown separately.

\section{Results}

\section{Babesiosis}

A. Clinical babesiosis. Eleven out of 24 adult cattle inoculated with $B$. divergens fell ill in clinical babesiosis and they had to be treated. Seven of the 13 animals of Group 3 showed a moderate to high parasitaemia at the day of treatment, $0.2-2.6 \%$ of the erythrocytes being infected.

B. Subclinical babesiosis. Thirteen adult cattle and all 15 calves developed a subclini- cal babesiosis, only detectable serologically in some of them. The number of animals reacting clinically was significantly different $(\mathrm{p}<0.01)$.

\section{Parasitaemia}

Sixteen $(57 \%)$ of the 28 animals responded with a parasitaemia, i.e. at least 1 infected $\mathrm{rbc} / 10^{6}$ were detected in the blood smears (Table 2). Six $(40 \%)$ of the calves and 10 $(77 \%)$ of the adult were positive. The parasitaemia was very mild in calves and significantly pronounced in a high proportion of adult animals.

The time which elapsed from inoculation to the first appearance of $B$. divergens in blood films (incubation period) varied from 4 to 11 days, the average time \pm SD being $6.8 \pm 1.8$ days. There was no significant difference between age categories (Table 3 ).

The duration of the first parasitaemia in individual animals lasted 1 to 3 days. Duration

Table 3. Parasitaemia: Distribution of animals on no. days p.i. when parasites first were detected in cattle experimentally inoculated with $B$. divergens.

\begin{tabular}{|c|c|c|c|c|c|c|c|c|}
\hline Group & $\begin{array}{c}\text { No. of animals } \\
\text { with a parasit- } \\
\text { aemia }\end{array}$ & 4 & 5 & 6 & $\begin{array}{l}\text { anir } \\
\text { sits } \\
7\end{array}$ & $\begin{array}{l}. \mathrm{sh} \\
\mathrm{mi} \\
8\end{array}$ & $\begin{array}{l}\text { wing their first } \\
\text { on Day p.i. } \\
910 \\
9\end{array}$ & $\begin{array}{l}\text { Average duration of } \\
\text { parasitaemia, days }\end{array}$ \\
\hline $\begin{array}{l}\text { Calves } \\
1 \\
2\end{array}$ & $\begin{array}{l}2 \\
4\end{array}$ & 1 & & 1 & 2 & 2 & & $\begin{array}{l}0.4 \\
0.4\end{array}$ \\
\hline $\begin{array}{l}\text { Cows } \\
3\end{array}$ & 10 & 1 & 2 & 1 & 3 & 1 & 1 & $1.8^{*}$ \\
\hline
\end{tabular}

*Seven animals treated when body temperature $\geq 40^{\circ} \mathrm{C}$. The untreated adults had a parasitaemia lasting 1 day. 
Table 4. Sequential development of parasitaemia and other clinical parameters in individual adult cattle (Group 3) after experımental inoculation of Babesia divergens.

\begin{tabular}{|c|c|c|c|c|c|c|c|c|c|c|c|c|c|c|c|c|c|c|c|c|c|c|c|c|c|c|c|c|c|c|c|c|}
\hline \multirow[t]{3}{*}{$\begin{array}{l}\text { Anımal } \\
\text { no }\end{array}$} & \multicolumn{8}{|c|}{$\begin{array}{c}\text { Parasitaemia no of inf } \\
\mathrm{rbc} / 10^{4} \mathrm{rbc}\end{array}$} & \multicolumn{8}{|c|}{$\begin{array}{c}\text { Body temperature } \\
\text { increse above } 393^{\circ} \mathrm{C}\end{array}$} & \multicolumn{6}{|c|}{$\begin{array}{l}\text { Loose fecal } \\
\text { consistency }\end{array}$} & \multicolumn{8}{|c|}{$\begin{array}{c}\text { Milk loss estımate } \\
1-4(25-100 \%)\end{array}$} & \multirow{2}{*}{\multicolumn{2}{|c|}{$\begin{array}{l}\text { Day p } 1 \\
\text { of of } \\
\text { sero- tre- }\end{array}$}} \\
\hline & & & & Day & $p l$ & & & & & & & Day & $p l$ & & & & & & Day & $p t$ & & & & & & Day & $p l$ & & & & & \\
\hline & 4 & 5 & 6 & 7 & 8 & 9 & 10 & 11 & 5 & 6 & 7 & 8 & 9 & 10 & 11 & 12 & 6 & 7 & 8 & 9 & 10 & 11 & 5 & 6 & 7 & 8 & 9 & 10 & 11 & 12 & conv & at \\
\hline 1 & 1 & 9 & 100 & & 01 & & & & 6 & 1 & & & & & & & $x$ & & & & & & & 3 & & & & & & & 7 & 6 \\
\hline 2 & & & & & 100 & & & & & & 2 & 10 & & & & & & $x$ & $\mathbf{x}$ & & & & & & & 3 & & & & & 9 & 8 \\
\hline 3 & & & & 1 & 51 & & & & & & 2 & 14 & & 5 & & & & $\mathbf{x}$ & $\mathbf{x}$ & & & & & & & 3 & 2 & & & & 7 & 8 \\
\hline 4 & & 5 & 50 & & & & & & 1 & 15 & 3 & & & & & & $x$ & & & & & & 1 & 4 & 2 & & & & & & 7 & 6 \\
\hline 5 & & & 2 & 120 & & & & & & 2 & 7 & & & & & & & $x$ & & & & & & 2 & 3 & & & & & & 9 & 7 \\
\hline 6 & & 1 & 21 & & & & & & 1 & 5 & & & & & & & $x$ & & & & & & & 1 & 2 & & & & & & 7 & 6 \\
\hline 7 & & & & & & & & 260 & & & & & & 5 & 18 & 9 & & & & & $x$ & $\mathbf{x}$ & & & & & & 2 & 3 & 4 & 7 & 11 \\
\hline 8 & & & & & 01 & & & & & & 1 & 3 & & & & & & & $\mathbf{x}$ & & & & & & & 2 & 1 & & & & 7 & \\
\hline 9 & & & & & & & & & & 1 & & & & & & & & & & & & & & & & & & & & & 9 & \\
\hline 10 & & & & & & & & & & & 1 & 5 & & & & & & & $\mathbf{x}$ & & & & & & & 1 & & & & & 9 & \\
\hline 11 & & & & & & & & & & & & 3 & & & & & & & $x$ & & & & & & & 1 & 1 & & & & 9 & \\
\hline 12 & & & & & & 1 & & & & & & & 6 & & & & & & & $\mathbf{x}$ & & & & & & & 2 & & & & 7 & \\
\hline 13 & & & & 1 & & & & & & & 1 & 4 & & & & & & & $x$ & & & & & & & 1 & & & & & 7 & \\
\hline
\end{tabular}

of more than 1 days was only observed among cows which had clinical symptoms. In some animals parasites reappeared within 2 days, but then lasted just for 1 day (Table 4).

Ehrlichia phagocytophilia was not found in any thin film examined.

\section{Packed cell volume}

The mean PCV values are shown in Fig. 1. The mean PCV values of Groups 2 and 3 gradually decreased to $5-10 \%$ of the preinfection values until Days 11 to 15 p.i. and then it began to return to the preinfection level. There was no difference in the PCV de-

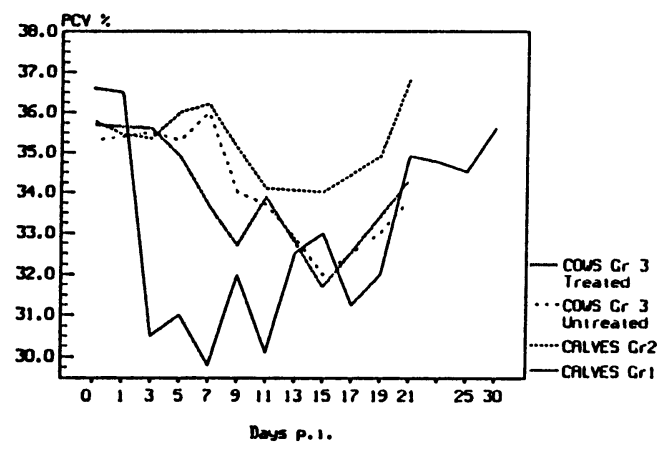

Figure 1. Mean PCV of calves 1.5-2 months old (Group 1), calves 7-11 months old (Group 2) and treated and untreated diary cows (Group 3 ) after inoculation with Babesia divergens. crease between these calves and untreated cows. The PCV values of treated adults also decreased about $10 \%$. They were then affected by treatment, but returned to the preinfection levels within the same period of time as the untreated animals. The mean PCV values of the very young calves in Group 1 responded within 3 days p.i. and remained low for 2 weeks before approaching preinfaction values.

\section{Body temperature}

All adult animals (Groups 3 and 4) and 10 of the calves responded with fever $\left(\geq 39.4^{\circ} \mathrm{C}\right)$, cows significantly more than calves ( $p$

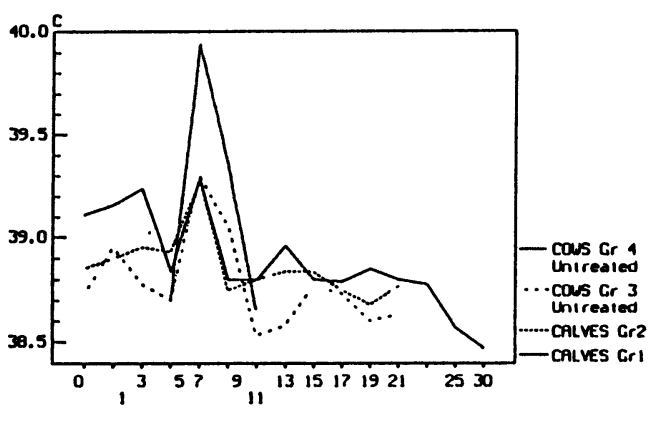

Days P.1.

Figure 2. Mean body temperature $\mathrm{C}^{\circ}$, of calves 1.5 2 months old (Group 1), calves 7-11 months old (Group 2) and untreated diary cows (Group 3 and Group 4) after inoculation with Babesia divergens. 
$<0.05)$. Eleven of the cows had high fever $\left(\geq 40.0^{\circ} \mathrm{C}\right)$ but just 2 of the calves ( $p$ $<0.05)$. The daily average fever values are shown in Fig. 2. The average fever values peaked on Day 7 p.i. except for Group 1. The average sum of the daily febrile response $\left(>39.3^{\circ} \mathrm{C}\right)$ is summarized in Table 5 . It was significantly higher for cows than for calves although about every other adult was treated. Of the 16 animals which showed a parasitaemia at the day of maximum temperature coincided with the day of maximum parasitaemia with one exception.

Table 5. Body temperature: sum of individual daily febrile response $\geq 39.4^{\circ} \mathrm{C}$ after experimental inoculation with $B$. divergens.

\begin{tabular}{lcc}
\hline Group & No. of animals & $\begin{array}{c}\text { Mean temperature } \\
\geq 39.4^{\circ} \mathrm{C}\end{array}$ \\
\hline Calves & 5 & 0.3 \\
1 & 10 & 0.4 \\
2 & & \\
Cows & 6 & 0.4 \\
3 (untreated) & 7 & 1.6 \\
4 (untreated) & 7 & 1.5 \\
3 (treated)* & 4 & 3.4 \\
4 (treated) $^{* *}$ & &
\end{tabular}

*treated at a temperature of $\geq 40^{\circ} \mathrm{C}$

**treated when haematuria was observed

\section{Other clinical signs}

Haemoglobinuria was recorded only in adult animals. Four of 11 animals of Group 4 displayed this reaction.

Soft faecal consistency was seen in 12 of 13 cows of Group 3 and all animals of Group 4. All other animals had normal faeces. Loose stools occurred simultaneously with fever (Table 4).

The dairy cows in Group 3 had the maximum depression of milk yield simultaneously with the increased body temperature (Table 4). There was also close association between fever and lowered milk yield.

The appetite of the calves was uninfluenced by the subclinical babesiosis. Among the animals in Group 3, a reduced appetite was reported by the farmer when milk production was depressed.

\section{Serology}

B. divergens-specific antibodies appeared in all of the animals, the titre rise beginning between Days 5 and 9 p.i. There was no significant difference between young and adult animals. Already on Day 7 p.i. 16 out of 28 $(71 \%)$ of the animals were seropositive.

The daily average antibody titre responses during the first 21 days p.i. followed a similar pattern in young and adult animals (Fig. 3). The changes in average antibody titres of treated and untreated adults were almost parallel (Fig. 3). Specific antibodies were established whether a parasitaemia was demonstrable or not. The serological response occurred in most cases within 1 to 2 days after the parasitaemia but in some cases antibodies were demonstrated before the parasites (Table 4). The minimum antibody titre value on Day 21 p.i. was 1/1280.

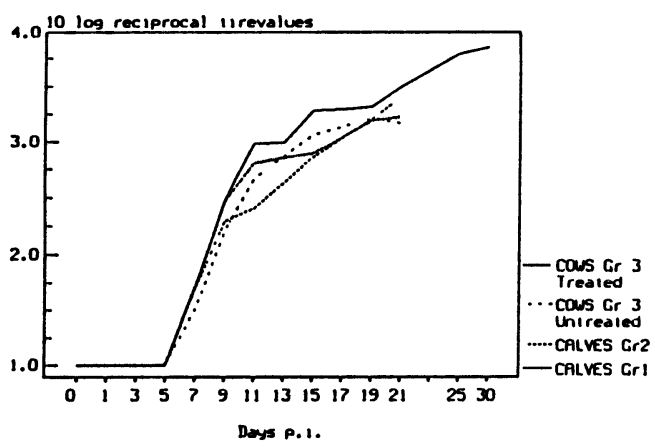

Figure 3. Mean and point IF-titre (IgG) values as ${ }^{10} \mathrm{log}$ of the reciprocal titre value of calves $1.5-2$ months old (Group 1), calves 7-11 months old (Group 2) and untreated and treated diary cows (Group 3) after inoculation with Babesia divergens.

\section{Treatment}

Seven animals in Group 3 and 4 animals in Group 4, which responded with clinical babesiosis, were successfully treated. 


\section{Discussion}

This investigation shows that dairy cows are more susceptible than calves to experimentally inoculated $B$. divergens organisms. The inoculate generated a high parasitaemia, fever, haemoglobinuria, inappetence and reduced milk production in a high proportion of the dairy cows. In contrast no calves showed evidence of clinical babesiosis.

This is in agreement with own field studies (Christensson \& Morén 1987, Christensson \& Thorburn 1987, Christensson \& Enfors 1987). A similar age dependent pattern was reported previously for $B$. bovis and $B$. bigemina (Smith et al. 1978, Trueman \& Blight 1978, Latif et al. 1979).

There were great within-age-group variations in parasitaemia (Table 2). This seems to be a natural individual response of cattle to $\boldsymbol{B}$. divergens, which has been observed previously in experimental studies (Davies et al. 1958, Trees 1978, Purnell 1981, Taylor et al. 1986b) but not to $B$. bovis or B. bigemina (Trueman \& Blight 1978, Smith et al. 1978, Latif et al. 1979). An explanation for this difference may be that these two Babesia species are more virulent and they may cause severe disease and high mortality even among yearlings. Only about half of the $B$. divergens-inoculated adults in this study developed a clinical babesiosis, a result not always observed in small groups of animals (Brockesly et al. 1971).

The PCV values showed great individual variations but there was no difference between age groups (Fig. 1), probably because of treatment of animals already at the point of a high febrile reaction. The mean percentage reduction of PCV was limited to $5-10 \%$ within 2 weeks as in subclinically affected cows and calves (Fig. 1). it is obvious that the parasitaemia was too low and of too short a duration to cause a significant drop in the PCV-values of these animals compared to the reports of Smith et al. (1978), Trueman $\&$ Blight (1978) and Taylor et al. (1983). The drop in PCV-values occurred in every animal independent of age and in calves was often the only subclinical reaction to the inoculation besides a seroresponse. A drop of the PCV-values even in animals reacting subclinically to $B$. divergens was reported earlier by Brocklesby et al. (1971) and Taylor et al. (1983).

The average temperature of cows and calves peaked on Day 7 p.i. simultaneously in most animals with a parasitaemia (Fig. 2) except for the group of the youngest calves (Group 1). This probably because the two calves having a parasitaemia and a small febrile response reacted earlier (Tables 2 and 3). Dairy cows were more sensitive to the inoculated $B$. divergens organisms as shown by the elevated body temperature which was recorded at some time in every adult, even in those with an undetectable parasitaemia (Table 4). In contrast, an incresed body temperature was recorded only in those calves with a parasitaemia. The incidence of temperature $\geq 39.4^{\circ} \mathrm{C}$ after infection was significantly more common in cows than in calves. There was a close correlation between the day(s) of parasitaemia and the day(s) of elevated temperature. However, the animals had too low a parasitaemia of too short a duration to allow any correlations with the values of the parasitaemia and PCV or body temperaturevalues as previously reported by Callow \& Pepper (1974) for B. bovis and by Purnell et al. (1977b) for $B$. divergens in splenectomized calves.

Most dairy cows also showed depressed milk production and loose stools coinciding with the maximum body temperature (Table 4). These symptoms are, beside fever, the first signs of acute babesiosis in adults (Bergman \& Waxberg 1915). Haemoglobinuria occurred only in animals in Group 4 after 1 or 2 days of febrile response. 
All animals responded with antibody formation (IgG). This response was independent of age and the degree of parasitaemia. The kinetics of the antibody response were similar in cows and calves (Fig. 3). The clinical manifestation in a high proportion of cows and the severity of the parasitaemia in subclinically affected cows in comparison with these parameters in calves demonstrates that primary IgG antibody formation is not the responsible factor involved in the inverse age resistance phenomenon. The results reported in newborn calves (Christensson 1987b) and in older calves, yearlings and adults ( $\mathrm{La}$ tif 1979, Taylor et al. 1983) supports this conclusion. The antibody system responded even to an undetectable parasitaemia. In fact antibodies could be demonstrated before infected erythrocytes appeared in blood smears (Table 4). Consequently these antibodies had no inhibitory effect on the multiplication of Babesia organisms in the primary infection. This finding is somewhat in contrast to the results reported by Mahoney \& Goodger (1972), Todorovic et al. (1973), Purnell \& Brocklesby (1977). These authors demonstrated a protective effect of hyperimmune serum in primary Babesia infections. Specific immunity to reinfection with Babesia is also reported to be antibody-mediated (Callow \& Dalgliesh 1982).

The first IgG antibodies were demonstrated in every animal at some point between 5 and 9 days after inoculation of $\boldsymbol{B}$. divergens. The end point titre values on Day 21 p.i. were $1 / 1280-5120$. The same pattern of the humoral antibody response after infection with Babesia organisms was observed previously when the IF-technique or other tests to demonstrate specific IgG or Ig were applied (Ross \& Löhr 1968, Purnell et al. 1976b, Todorovic \& Long 1976, Bidwell et al. 1978, Trees 1978, Latif et al. 1979, Rief 1980, Weiland et al. 1980, Dwivedi \& Gautam 1982,
O'Donoghue et al. 1985). Another interesting observation was that cows treated in the early phase of parasitaemia and fever had an IgG antibody response comparable to that of subclinically affected cows which were untreated (Fig. 3).

There are conflicting opinions on the role of antibodies in inverse age resistance. Hall (1963), Hall et al. (1968), Löhr (1969), Ross \& Löhr (1970) and Weisman et al. (1974) explained the phenomenon as a result of maternally transferred immunity followed by an early, natural infection.

The present study shows that this is not necessarily the only explanation. Support for this statement comes from reports that calves and yearlings beyond the reach of maternally acquired resistance fall ill in babesiosis in a lower frequency than adult cattle (Riek 1968, Trueman \& Blight 1978, Callow \& Dalgliesh 1982).

It may be speculated that the inverse age resistance and also the different individual response to $B$. divergens are related to a nonantibody factor in blood of young calves as previously suggested by Levy et al. (1982). An individual variation of the susceptibility has also been demonstrated among Trypanotolerant cattle (Murray et al. 1982, Murray \& Trail 1986), a phenomena which also is not completely explained.

Immunosuppression is another factor which may be age-related in Babesia infection in mice (Habicht et al. 1983). Concomitant infections with bacteria, e.g. Corynebacterium parvum, may inhibit the development of babesiosis in mice by stimulating a nonspecific immunity (Clark et al. 1976, Clark 1979, Cox 1980). This, however, failed to be proved for cattle (Brocklesby \& Purnell 1977) or was not statistically significant (Corrier \& Wagner 1984). Interactions between Babesia spp. and other parasites have been described. Millot \& Cox (1985) found a 
resistance to Babesia after a chronic Trypanosoma brucei infection. Suppressive effects on Babesia infection have been reported in rodents infected with Schistosoma mansoni (Fagbemi et al. 1985) and Taenia metacestodes (Nichol \& Sewell 1984).

The animals in this study showed no symptoms of any specific disease to indicate an interaction with the Babesia experiments. Ehrlichia phagocytophilia may interfere with the clinical symptoms of a simultaneous $B a$ besia infection (Purnell et al. 1976a, 1977a, Taylor et al. 1986a) This rickettsia has been found in Swedish cattle and sheep (Christensson, unpublished). However, any interaction with this pathogen may be excluded because $E$. phagocytophilia was not demonstrated.

In conclusion there exists an inverse age resistance to experimental $B$. divergens infection in cattle. Calves and cows become equally infected with $B$. divergens but a high proportion of dairy cows responds with clinical symptoms, while calves are affected to minor extent. The difference in the clinical responses of young and adult animals is not related to the kinetics of the IgG antibody response.

\section{References}

Bergman AM, Waxberg $H$ : Om blodstallning, piroplasmos hos notkreatur i Sverige (About red water fever, piroplasmosis in cattle in Sweden). Skand. Vet. tidskr. 1915, 5, 23-40.

Bidwell DE, Turp P, Joyner LP, Payne RC, Purnell $R E$ : Comparison of serological tests for Babesia in British cattle. Vet. Rec. 1978, 103, 446-449.

Brocklesby DW, Purnell RE: Failure of BCG to protect calves against Babesia divergens infection. Nature 1977, 265, 343.

Brocklesby DW, Harness E, Sellwood SS: The effect of age on the natural immunity of cattle to Babesla divergens. Res. Vet. Sci. 1971, 12, 15-17.

Callow LL: Vaccination against bovine babesiosis. In: Immunity to blood parasites of animals and man. (ed. Miller, L. H., J. A. Pino \& J. J. McKelvey Jr.). Advances in experimental medicine and biology. Plenum Press, New York 1977, 93, 121-150.

Callow LL, Dalgliesh RJ: Immunity and immunopathology in babesiosis. In: Immunology of parasitic infections. (ed. Cohen S., \& K. Warren). Blackwell Scientific Publications, Oxford 1982, p. 475-526.

Callow LL, Pepper PM: Measurements of and correlations between fever changes in the packed cell volume and parasitaemia in the evaluation of the susceptibility of cattle to infection with Babesia argentına. Aust. vet. J. 1974, 50, 1-5.

Christensson DA: Clinical and serological response after experimental inoculation with Babesia $d_{l}$ vergens of newborn calves with and without maternal antibodies. Acta vet. scand. 1987a, 28, 391-392.

Christensson DA: A modified IF-test to demonstrate IgM antibodies to Babesia divergens of cattle. Acta vet. scand. 1987b, 28, 361-371.

Christensson DA, Enfors $E$ : An outbreak of babesiosis ( $B$. divergens) in a dairy herd comprising different age groups of cattle. Acta vet. scand. 1987, 28, 125-126.

Christensson DA, Morén T: Seroresponse (IgG) after vaccination and natural infection of cattle with Babesia divergens. Acta vet. scand. 1987, 28, 393-402.

Christensson DA, Thorburn MA: Age distribution of naturally occurring acute babesiosis in cattle in Sweden. Acta vet. scand. 1987, 28, 373-379.

Clark IA: Protection of mice against Babesia microti with cord factor, COAM, zymosan, glucan, Salmonella and Listeria. Parasite Immunol. 1979, 1, 179-196.

Clark IA, Allison AC, Cox FEG: Protection of mice against Babesia and Plasmodium with BCG. Nature 1976, 259, 309-311.

Corrier DE, Wagner $G G$ : The protective effect of pretreatment with killed Corynebacterium parvum against acute babesiosis in calves. Vet. Parasitol. 1984, 15, 165-168.

Cox FEG: Non specific immunity against babesiosis. In: Isotope and radiation research on animal diseases and their vectors. IAEA, Vienna 1980, p. 95-108. 
Davies SF, Joyner LP, Kendall SB: Studies on Babesia divergens (M'Fadyean and Stockman 1911). Ann. trop. Med. Parasit. 1958, 52, 206-215.

Dwived $S$, Gautam OP: A note on comparative eff1cacy of indirect haemagglutination (IHA), capillary tube agglutanitation (CA) and indirect fluorescent antibody (IFA) test(s) in the diagnosis of experimental babesiosis in calves. Indian vet. $J$. 1982, 59, 404-406.

Fagbemı BO, Christensen NO, Nansen P: Suppression of Babesia microti infection in mice concurrently infected with Fasciola hepatıca. Vet. Parasitol. 1985, 17, 101-110.

Gray JS, Murphy TM: Bovine babesıosis in Ireland. I. News, 1985, 9-14.

Gray JS, Fitzgerald E, Strichland KL: Prevalence of clinical babesiosis in North Co. Meath, Ireland. Vet. Rec. 1983, 113, 537-539.

Habıcht GS, Benach JL, Leichtling KD, Gocınskl $B L$, Coleman JL: The effect of age on the infection and immunoresponsiveness of mice to Babesia microtı. Mech. \& Dev. 1983, 23, 357-369.

Hall VTK: The immunity of Babesia argentına infection. Aust. vet. J. 1960, 36, 361-366.

Hall VTK: The immunity of calves to tick-transmitted Babesıa argentına infection. Aust. vet. J. 1963, 39, 386-389.

Hall VTK, Tammemagl L, Johnston LAY: Bovine babesıosıs; The immunity of calves to Babesia blgemına infection. Aust. vet. J. 1968, 44, 259-264.

Hindersson R: Om skyddsympning mot och behandling av piroplasmos hos notkreatur. (About protective inoculation of and treatment of bovine piroplasmosis). 3 Nordiske Vet. Oslo, 9-11 juli 1928, p. 192-209.

Kların E: Blodstallning hos notkreatur. Piroplasmosis bovis. Berattelse over bolagets trettiofemåriga verksamhet (Redwater fever in cattle. Piroplasmosis bovis. Report on the activities of the last 35 years of the company). Skandinaviska Kreatursforsakrıngsbolaget, Stockholm 1925, p. 80-98.

Kragerud A: Hamoglobinurie beim Rinde. (Haemoglobınuria in cattle). Z. Tiermed. 1901, 5, 284-290.

Latlf BMA, Sald MS, All SR: Effect of age on the immune response of cattle infected with Babesia bigemına. Vet. Parasitol. 1979, 5, 307-314.
Legg J: A brief review of the piroplasms with special reference to the type found in Australian $» r e d w a-$ ter«. Aust. vet. J. 1933, 9, 14-19.

Levy MG, Clabaugh $G$, Rlstıc $M$ : Age resistance in bovine babesiosis: role of blood factors in resistance to Babesia bovis. Inf. Immun. 1982, 37, 1127-1131.

Lohr K-F: Beitrag zur Frage der naturlichen Resistenz von Kalbern gegen die Infektion mit Babesia bigemina. (Contribution tot he question of natural resistance of calves to infection with $B a$ besia bigemina). Zentbl. Vet. Med. 1969, 16, 158-163.

Mahoney DF, Goodger BV: Babesıa argentına: immunogenicity of plasma from infected animals. Exp. Parasitol. 1972, 32, 71-85.

Millot SM, Cox FEG: Interactions between Trypanosoma brucel and Babesia spp. and Plasmodium spp. in mice. Parasitology 1985, 90, 241254.

Murray M, Trail JCM: Comparative epıdemiology and control of trypanosomiasis. In: Parasitology - Quo Vadit? Proceedings of the Six International Congress of Parasitology. (Ed: M. J. Howell). Australian Academy of Science, Canberra 1986, p. 621-627.

Murray M, Morrison WI, Whitelaw DD: Host susceptibility to African trypanosomiasis: trypanotoloreance. In: Advances in Parasitology (eds: Baker, J. R. \& R. Muller). Academic Press, London 1982, vol. 21, p. 1-68.

Nichol CP, Sewell MMH: Immunodepression by larvalcestodes of Babesia microtl infections. Ann. trop. Med. Parasitol. 1984, 78, 228-233.

O'Donoghue PJ, Friedhoff KT, Vizcaino OG, Weyreter $H$ : The detection of IgM and IgG antibodies against Babesıa bıgemına in bovine sera using semi-defined antigens in enzyme immunoassays. Vet. Parasitol. 1985, 18, 1-12.

Pipano E: Immunization of cattle against Babesiella berbera infection I. Infection of cattle with blood from patent and latent carriers. Refuah Vet. 1969, 26, 11-18.

Pound CJ: Tick fever. Notes on the inoculation of bulls as a preventive against tick fever at Rathdowney and Rosedale. Qd.agric. J. 1897, 1, 473477.

Purnell RE: Babesiosis in various hosts. In: Babesiosis (ed. Ristic, M. \& J. P. Kreier). Academic Press, New York, 1981a, p. 25-64. 
Purnell RE, Brocklesby DW: Babesia divergens in splenectomized calves: immunogenicity of lyophilized plasma from an infected animal. Res. Vet. Scı. 1977, 23, 255-256.

Purnell RE, Lewis D: Babesia divergens: combination of dead and live parasites in an irradiated vaccine. Res. Vet. Sc1. 1981, 30, 18-21.

Purnell RE, Brocklesby DW, Hendry DJ, Young ER: Separation and recombination of Babesia divergens and Erlichia phagocytophilia from field case of redwater from Eire. Vet. Rec. 1976a, 99, 415-417.

Purnell RE, Hendry DE, Bidwell DE, Turp P: Microplate enzyme linked immunosorbent assay for antibody to Babesia divergens in cattle. Vet. Rec. 1976b, 99, 102.

Purnell RE, Young ER, Brocklesby DW, Hendry $D J$ : The haematology of experimental induced $B$. divergens and E. phagocytophlia infections in splenectomized calves. Vet. Rec. 1977a, 100, 4-6.

Purnell RE, Brocklesby DW, Hendry DJ, Stark AJ, Young ER: Babesia divergens in splenectomized calves: titration of the infective dose. Res. Vet. Sc1. 1977b, 23, 124-125.

Rief L: Der serologische Nachweis der Babesia divergens-Infektıon des Rindes mit der Immunofluoreszenz, der indirekten Hamagglutination und dem Immuno-Enzymtest. (Serological detection of Babesia divergens infection in cattle by immunofluorescence, indirect haemagglutination and enzyme linked immunosorbent assay). Thesis, Ludwıg Maxımılian Unıversitat, Munchen 1980.

Riek RF: Babesiosis. In: Infectious Blood Diseases of Man and Animals. (ed: Weinman, D., \& M. Ristic). Academic Press, London 1968, p. 246248.

Ross JPJ, Lohr K-F: Serological diagnosis of B. blgemina infection in cattle by the indirect fluorescent antıbody test. Res. Vet. Sci. 1968, 9, $557-$ 562.

Ross JPJ, Lohr K-F: Ubertragung und Verweildauer von kolostral erworbenen Babesia bıgemina und Anaplasma marginale-Antikorpern. (Transmission and duration of colostral derived antibodies to Babesia bigemına and Anaplasma margınale). Z. Tropenmed. Parasitol. 1970, 21, 401-411.

Smith RD, Osorno BM, Brener J, De La Rosa R, Rlstic $M$ : Bovine babesiosis: severity an reproduci- bility of Babesia bovis infection induced by Boophılus microplus under laboratory conditions. Res. Vet. Sci. 1978, 24, 287-292.

Smith T, Kulborne FL: Investigation into the nature, causation and prevention of Texas or Southern cattle fever. U.S.D.A. Bur. Anim. Ind. 1893, 1, 1-301.

Taylor SM, Kenny J, Mallon T: The effect of multiple rapid passage on strains of Babesia divergens: a comparison of the clinical effects on juvenile and adult cattle of passaged and irradiated parasites. J. comp. Pathol. 1983, 93, 391-396.

Taylor SM, Elliott CT, Kenny J: Inhibition of Babesia divergens in cattle by oxytetracycline. Vet. Rec. 1986a, 118, 98-102.

Taylor SM, Elliot CT, Kenny J: Babesıa divergens: sequential exposure of heterologous tick-borne challenge of cattle immunized with a fraction of parasitized erythrocytes. J. comp. Pathol. 1986b, 96, 101-107.

Todorovic RA, Gonzalez EF, Adams LG: Bovine babesiosis: sterile immunity to Babesia bıgemına and Babesia argentına infections. Trop. \& Prod. 1973, 5, 234-245.

Todorovic $R A$, Long RF: Comparison of indirect fluorescent antibody (IFA) test with the complement fixation (CF) test for diagnosis of Babesia spp. in Colombian cattle. Tropemed. Parasitol. 1976, 27, 169-181.

Trees AJ: The application of acridine orange staining to quantitate low levels of Babesia divergens parasitaemias. Trans. R. Soc. trop. Med. Hyg. 1974, 68, 277.

Trees $A J$ : Indirect fluorescent antibody levels in experimental Babesia divergens infection of cattle. Res. Vet. Sci. 1978, 24, 126-128.

Trueman HF, Blight $G W$ : The effect of age on resistance of cattle to Babesia bovis. Aust. vet. J. 1978, 54, 301-305.

Welland G, Rief L, Schmidt M, Boch J: Serologische Untersuchungen zum Nachweis der Babesia divergens-Infektion des Rindes. (Serological investigations on Babesia divergens infections in cattle). Berl. Munch. tierarztl. Wschr. 1980, 93, 261264.

Weisman J, Goldman M, Mayer E, Pipano E: Passive transfer to newborn calves of maternal antibo- 
dies against Babesıa bigemına and Babesia berbe$r a$. Refuah Vet 1974, 31, 108-113.

Winter $H$ : Stainıng with acridine orange. Res. Vet. Sc1. 1967, 8, 170.

\section{Sammanfattning}

Omvand åldersresistens hos notkreatur vid experlmentell infektion med Babesia divergens.

Kalvar och mjolkkor inokulerades i.v. med $3 \times 10^{7}$ erythrocyter infekterade med Babesia divergens, dvs. samma dos som , \VA's vaccin mot babesios. Halften av de vuxna djuren sıarade med hog parasitemı, hos en grupp aven med hemoglobinurı. Flertalet vuxna djur hade teber 1 samband med en parasitem samt los avforing och minskad mjolkproduktion. Kalvarna visade ınga klinıska symtom men en låggra- dıg parasitemi kunde påvisas hos knappt halften av djuren. Dessa skillnader visar på en omvand åldersresistens mot $B$. divergens.

Kinetik och titernivå i det uppmatta humorala antikroppssvaret (IgG) var daremot likartade oavsett åldersgrupp. Det ar darfor osannolikt att produktionen av dessa IgG-antikroppar har en avgorande betydelse for det primara infektionsforloppet och darmed aven for den omvanda åldersresistensen. Antikroppssvaret var ej beroende av parasitemins storlek eller om varddjuret behandlats i akut sjukdomsskede

Endast hos ca halften av djuren 1 respektive åldersgrupp utvecklades en påvisbar parasitemi. Detta v1sar att andra faktorer an åldern som sådan inverkar på babesıosens klınıska forlopp.

(Recelved February 21, 1989, accepted March 2, 1989).

Reprints may be requested from: Dan Christensson, National Veterınary Institute, P. O Box 7073, S-75007 Uppsala, Sweden. 